\title{
Wydawnictwo Adam Marszałek o twórcach nauki, kultury i polityki
}

\section{Wydawnictwo Adam Marszałek - jego profil i oferta wydawnicza}

W 2012 r. minęło 22 lata od powstania Wydawnictwa Adam Marszałek (WAM) ${ }^{1}$. Historię powstania i rozwoju tej oficyny wydawniczej można poznać dzięki lekturze księgi jubileuszowej opublikowanej z okazji dwudziestolecia jej istnienia $^{2}$. Sporo informacji na temat funkcjonowania tej instytucji uzyskałam dzięki wywiadom przeprowadzonym z prezesem Wydawnictwa dr Adamem Marszałkiem $^{3}$. Dla zgłębienia profilu i celów działania WAM wykorzystałam także źródła

* Prof. zw. dr hab., Uniwersytet Mikołaja Kopernika w Toruniu, Wydział Nauk Pedagogicznych, Kierownik Katedry Historii Myśli Pedagogicznej, 87-100 Toruń, ul. Gagarina 9.

1 Tekst ma jedynie charakter informacyjny i nie pretenduje do miana wypowiedzi naukowej. Traktuję go jako głos w dyskusji na temat WAM jako jednej z oficyn wydawniczych w Polsce i jej znaczenia w rozwoju nauki i kultury.

2 Dwadzieścia lat minęło... Księga jubileuszowa Wydawnictwa Adam Marszałek, red. J. Orzeł, wyd. I, ss. 493 i wyd. Il poszerzone, ss. 529 Toruń 2010.

${ }^{3}$ Dr Adam Marszałek - absolwent historii na Uniwersytecie Mikołaja Kopernika w Toruniu, ukończył także Podyplomowe Studia Politologiczno-Pedagogiczne w 1977 r. Odbył staże zagraniczne w Moskwie i Paryżu, a w 1884 r. uzyskał stopień doktora na UAM w Poznaniu. W latach 1976-1994 był pracownikiem naukowo-dydaktycznym na UMK. Pełnił liczne funkcje: m.in. prezesa Polskiego Towarzystwa Politologicznego, oddział w Toruniu, jest członkiem Komitetu Nauk Politycznych PAN, członkiem Zarządu Polskiego Towarzystwa Politologicznego. Za działalność został wyróżniony licznymi nagrodami i odznaczeniami, m.in. Srebrnym Krzyżem Zasługi, otrzymał: Nagrodę Literacką im. Władysława Reymonta, Nagrodę im. Jarosława Iwaszkiewicza za upowszechnianie literatury współczesnej, nagrodę „Polityki”, Nagrodę literacką Związku Pisarzy Ukrainy i in. Biogram opracowany na podstawie: Archiwum WAM, Pracownicy nauki i dydaktyki Uniwersytetu Mikołaja Kopernika 1945-1994. Materiały do biografii, red. S. Kalembka, Toruń 1995, s. 452. 
zarchiwizowane $w$ Wydawnictwie ${ }^{4}$ oraz artykuły z prasy lokalnej ${ }^{5}$. Ponadto od roku 2000 brałam udział w wielu spotkaniach promocyjnych $z$ autorami prac opublikowanych w WAM. Poza tym jestem autorką publikacji, które ukazały się w WAM oraz redaktorem naukowym serii, dzięki temu mogłam poznać zasady współpracy z tą instytucją. Z tych wszystkich źródeł wyłania się obraz wydawnictwa o określonym profilu. A we wspomnianej księdze jubileuszowej pt. Dwadzieścia lat minęło... o znaczeniu toruńskiej instytucji w życiu naukowym, społecznym i kulturalnym wypowiedzieli się autorzy prac, które ukazały się dzięki WAM, redaktorzy serii, a także wielu przedstawicieli świata nauki i polityki. W wypowiedziach tych odnajdujemy informacje o udziale WAM w promowaniu dorobku różnych dyscyplin nauki. A wypowiadali się m.in. profesorowie: historii (M. Kosman, K. Mikulski, A. Radzimiński, W. Wrzesiński), politologii (A. Chodubski, L. Pastusiak, T. Sasińska-Klas), pedagogiki (T. Lewowicki, A. Nalaskowski, B. Siemieniecki, W. Theiss) i wielu innych. Idea popularyzacji dorobku różnych dyscyplin naukowych przyświecała twórcy wydawnictwa i jego prezesowi dr. A. Marszałkowi od początku kierowania oficyną. W dziele tym od 2005 r. wspierała Go wiceprezes Wydawnictwa dr hab. Joanna Marszałek-Kawa ${ }^{6}$. Ona też objęła stanowisko prezesa WAM z dniem 1 stycznia 2013 r. Mówiąc o działalności WAM, należy zwrócić uwagę na jeszcze jedną ważną idee, którą kieruje się twórca tej oficyny, jest to pomoc w publikowaniu prac młodym adeptom nauki. Dlatego też ukazało się w WAM wiele debiutów, w tym prac magisterskich, które zostały nagrodzone na przykład w konkursie Towarzystwa Miłośników Torunia (ToMiTo) i uzyskały pozytywne recenzje ${ }^{7}$. Debiutują także z pierwszymi swymi pracami zwartymi doktorzy, którzy tuż po uzyskaniu stopnia,

4 Ważnych informacji dostarcza także strona internetowa WAM, a zwłaszcza zakładki o promocjach książek, nowościach, które są uzupełniane na bieżąco.

5 Głównie notatki bądź wywiady w: „Nowościach” (przykładowo w wydaniach 02.08.2007, 13.11.2007, 23.05.2008, 01.08.2009) i „Echu Świdwina”. To ostatnie pismo powstało w 1997 r. i od tego momentu rejestruje ważne wydarzenia z życia WAM. Czasopismo to można uznać za swoistego rodzaju „kronikę” działalności WAM. Jest to także promocja miasta rodzinnego dr. A. Marszałka.

${ }^{6} \mathrm{Dr}$ hab. Joanna Marszałek-Kawa - absolwentka prawa na Uniwersytecie Mikołaja Kopernika w Toruniu. W 2004 r. uzyskała stopień doktora w zakresie nauk politycznych UAM w Poznaniu, w 2012 r. stopień doktora habilitowanego na UMK. Jej zainteresowania naukowe koncentrują się wokół zagadnień systemu politycznego RP, systemów konstytucyjnych państw świata, samorządu terytorialnego. Opublikowała m.in.: Parlamenty jednoizbowe w państwach nordyckich. Pozycja i funkcjonowanie, Toruń 2004; Parlament Europejski V kadencji a parlamenty narodowe państw członkowskich Unii Europejskiej, Toruń 2005 oraz jej chińskiego wydania w 2011 r. (European Parliament and national parliaments in EU); Contemporary China. The conditions of the state, Toruń 2011 oraz jest współautorką (obok D. Kawy) D. Kawa, J. Marszałek-Kawa, Polska droga do Unii Europejskiej i jej odzwierciedlenie w prasie niemieckiej, Toruń 2007. Jest redaktorem naukowym serii wydawniczej: „Unia-Polska-Integracja”, „Biblioteka Azji i Pacyfiku”, „Oblicza mediów”, zastępcą redaktora naczelnego: „Polish Political Science. Yearbook”, „Athenaeum. Political Science”, członkiem rad naukowych m.in.: „Azji i Pacyfiku”, „Cywilizacji i Polityki”, „Krakowskich Studiów Małopolskich”, „Oblicza mediów”, „Polish Political Science. Yearbook”, „Politologii i Stosunków Międzynarodowych”, „The New Educational Review”, „The Pecaliurity of Man". W latach 2004-2010 pełniła funkcję zastępcy dyrektora Instytutu Politologii UMK, jest sekretarzem toruńskiego oddziału Polskiego Towarzystwa Nauk Politycznych. Biogram opracowany na podstawie: Archiwum WAM, dokumenty udostępnione przez J. Marszałek-Kawę.

7 O idei promowania dorobku młodych adeptów nauki dr A. Marszałek wspomina w wywiadzie Tomasza Bielickiego pt. Książka im droższa, tym węższe grono odbiorców, opublikowanym na łamach „Nowości”, 02.02. 2008. 
nie będąc jeszcze osobami znanymi w środowisku naukowym, zgłaszają się do dr. A. Marszałka z prośbą o możliwość opublikowania wyników swych badań.

W działalności WAM ważną rolę odgrywa współpraca międzynarodowa, która przybiera różne formy, m.in. są to: tłumaczenia obcych autorów lub publikacje prac Polaków mieszkających za granicą. Trzeba nadmienić, że istotnym przejawem współpracy międzynarodowej są kontakty z Chinami. W Chinach od początku 2007 r. funkcjonuje przedstawicielstwo pod nazwą Adam Marszalek Beijing Publishing Consulting Co. Ltd.

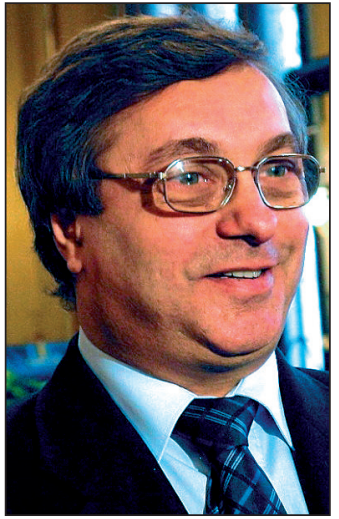

Adam Marszałek

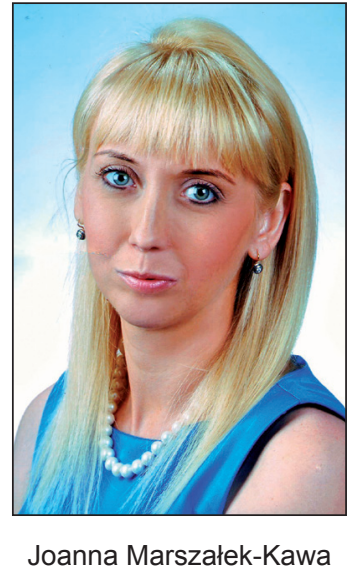

Joanna Marszałek-Kawa

Jaka jest oferta tej oficyny wydawniczej?

W ofercie WAM przeważają książki z zakresu historii, politologii, stosunków międzynarodowych, pedagogiki. Są także książki i inne wydawnictwa z filozofii, psychologii, a także z dziedzin filologicznych. Autorzy mogą publikować swoje prace $w$ wielu seriach wydawniczych, których redakcję tworzą znani uczeni, specjaliści w określonych dyscyplinach. Do najważniejszych należą m.in.: „Biblioteka Azji i Pacyfiku”, „Biblioteka Filologiczna”, „Biblioteka Historii Edukacji”, „Biblioteka ToMiTo”, „Biografie niezwykłe”, „Człowiek-Środowisko Życia-Edukacja”, „Dialog Europejski”, „Komunikacja Społeczna w Edukacji”, „Miasta i Ich Dzieje”, „Nauka o Komunikowaniu”, „Oblicza Mediów”, „Pedagogika Mediów”, „Problemy Współczesnego Świata”, „Przestrzenie życia społecznego”, „Samorząd terytorialny w XXI wieku”, „Staropolski Ogląd Świata”. Wśród różnych kategorii serii są także serie poetyckie: „Liryka polska”, „Dekada poetów”, „Duet”, „Polsko-rosyjska biblioteka poetycka". Twórcy wydawnictwa nie zapomnieli także o najmłodszych, co znalazło wyraz w cyklu utworów dla dzieci.

Bogato przedstawia się także lista czasopism wychodzących w WAM, jest aż 17 tytułów. Są to m.in.: „Atheneum. Polskie Studia Politologiczne”, „Edukacja

${ }^{8}$ Dane z roku 2012. Archiwum WAM. 
Międzykulturowa”, „Cywilizacja i Polityka”, „Polish Political Science Yearbook”, „Kultura i Edukacja”, „Krakowskie Studia Małopolskie”, „Colloquia Communia”, „Kognitywistyka i Media w Edukacji”, „Przegląd Prawa Konstytucyjnego”, „Świat Idei i Polityki”, „Samorząd i Społeczność Lokalna”, „The New Educational Review”, „Reality of Politics. Estimates, Comments, Forecasts”. Ponadto publikowane są wydawnictwa obcojęzyczne (w językach angielskim, niemieckim, francuskim, rosyjskim, włoskim i chińskim), kierowane do czytelników mieszkających za granicą.

\section{Biografistyka i literatura pamiętnikarska w WAM}

Propagowaniu wiedzy o twórcach nauki, kultury i polityki służą przede wszystkim prace o charakterze biograficznym oraz literatura pamiętnikarska9.

Przeglądając kategorie prac wyróżnionych w wydawnictwach polskich, można stwierdzić, że w każdym niemalże wydawnictwie oprócz prac z różnych dyscyplin naukowych odnajdujemy gatunki, na które składają formy pisarskie związane z ogólnie pojmowaną biografistyką. Zazwyczaj są to: Dzienniki, Wspomnienia, Listy, czyli tzw. literatura pamiętnikarska, a jako kategoria podstawowa występuje Biografia $^{10}$. W tej sytuacji należy zapytać, czym zatem wyróżnia się biografistyka publikowana w WAM? Po przeanalizowaniu działów wydawnictwa dotyczących biografistyki można sformułować ogólną opinię na ten temat. Otóż, należy stwierdzić, że po pierwsze jest to biografistyka dotycząca różnych dyscyplin naukowych, przy czym, jeśli chodzi o dyscypliny naukowe, dominują publikacje odnoszące się do historii, w tym historii nauki, polityki i życia społecznego oraz kulturalnego. Po drugie jest to biografistyka ukazująca różne sfery życia społecznego, politycznego, naukowego i oświatowego. Podając przykłady dla udowodnienia tej tezy, zacznijmy od informacji na temat serii pt. „Niezwykłe biografie”"11. W serii tej ukazały się znakomite publikacje napisane przez A. Żora ${ }^{12}$. Poświęcone one zostały Janowi Blochowi polskiemu bankierowi i przedsiębiorcy, twórcy i budowniczemu linii kolejowych, Janowi K. Steczkowskiemu polskiemu politykowi, ekonomiście, ministrowi skarbu oraz margrabiemu Aleksandrowi Wielopolskiemu kontrowersyjnemu politykowi, dyrektorowi KWRiOP, projektodawcy reformy oświatowej 1862 r., zwolennikowi polonizacji szkolnictwa. Zadaniem tej serii jest udostępnianie czytelnikowi wiedzy o zasłużonych, ale niekiedy zapomnianych twórcach życia gospodarczego, politycznego czy oświatowego.

Analizując książki naukowe o charakterze biograficznym, można stwierdzić, że na liście interesujących biografii, wydanych w toruńskiej oficynie, jako bohate-

${ }^{9}$ Obecnie w literaturze często na określenie pamiętników, wspomnień, listów i dzienników używa się terminu ego-dokumenty.

10 Bogatą ofertę w tym zakresie przedstawia Wydawnictwo Literackie.

11 Seria została zainicjowana i ufundowana przez Fundację BRE Banku i Fundację BGK im. Jana Kantego Steczkowskiego.

12 A. Żor, Figle historii, Toruń 2005; Ropucha. Studium odrzucenia, Toruń 2007; Człowiek na wielu krzesłach. Jan Kanty Steczkowski 1862-1929, Toruń 2009. 
rowie prac znaleźli się: uczeni i nauczyciele, a zarazem często działacze oświato$\mathrm{wi}^{13}$, politycy ${ }^{14}$, przedstawiciele duchowieństwa ${ }^{15}$ i twórcy kultury, poeci i pisarze ${ }^{16}$. Przy czym podział ten jest umowny, bowiem na przykład wielu znanych uczonych odegrało ważną rolę w polityce ${ }^{17}$.

Drugą ważną kategorią prac, które ukazały się na rynku wydawniczym dzięki omawianemu wydawnictwu, są ego-dokumenty. Trzeba podkreślić, że wśród wszystkich innych publikacji ten rodzaj publikacji liczbowo przedstawia się znacząco. W obrębie tej kategorii, czyli ego-dokumentów, można dokonać ich klasyfikacji, biorąc jako kryterium wykonywany zawód ich autorów. Tak też grupę autorów prezentują tu m.in.: wybitni uczeni, politycy i działacze społeczni oraz nauczyciele. Podajmy kilka przykładów. Dużą wartość dla badań historycznych, zwłaszcza z zakresu historii nauki polskiej, mają ego-dokumenty, które wyszły spod pióra wybitnych przedstawicieli nauki polskiej. Tytułem przykładu warto wymienić dzienniki twórcy szkoły Iwowsko-warszawskiej Kazimiera Twardowskiego ${ }^{18}$, wspomnienia historyka Jerzego Serczyka ${ }^{19}$, wspomnienia historyka i rektora Uniwersytetu Mikołaja Kopernika Sławomira Kalembki ${ }^{20}$ czy korespondencję Franciszka Bujaka, twórcy szkoły badawczej polskiej historii gospodarczej ${ }^{21}$.

Dla historyków oświaty wartościowe są ego-dokumenty, których autorami byli nauczyciele. Z nowszych publikacji WAM wskazać należy na wspomnienia W. Maćkowicza, polskiego „nauczyciela pogranicza”, uczestnika I wojny światowej, nauczyciela II Rzeczypospolitej i lat powojennych ${ }^{22}$, oraz pamiętnik J. Szuścika, nauczyciela związanego ze Śląskiem Cieszyńskim, będącego świadkiem wydarzeń przełomu XIX i XX w. ${ }^{23}$

${ }^{13}$ Bogactwo życia i twórczości Aleksandra Kamińskiego, red. I. Lepalczyk, W. Ciczkowski, Toruń 1999 i 2000; I. Lepalczyk, Helena Radlińska. Życie i twórczość, Toruń 2001; B. Szafraniec, Franciszek Bujak (1875-1953). Życie, działalność naukowo-dydaktyczna i społeczna, Toruń 2009; A. Wałęga, Wanda Szuman, Toruń 2005.

${ }^{14}$ K. Mikulski, Henryk Stroband (1548-1609) - burmistrz toruński, Toruń 2010; P. Żaroń, Generał Władysław Sikorski. żołnierz, mąż stanu, naczelny wódz 1939-1943, Toruń 2003; I. Stelmasik, Janusz Jędrzejewicz. Pedagog, wojskowy, ideolog i polityk. Zarys biografii 1885-1951, Toruń 2012.

15 W. Broniewski, Edyta Stein - obecna i bliska, Toruń 2004; M. Laskowska, Ksiądz Stefan Wyszyński jako dziennikarz i redaktor 1924-1946, Toruń 2011; J. M. Roth, Społeczno-polityczna działalność prymasa Polski Augusta Hlonda w latach 1939-1945, Toruń 2009.

${ }_{16}$ M. Korczyńska, Jerzy Zawiejski. Biografia humanistyczna, Toruń 2011; S. Sterkowicz, Człowiek - instytucja. Kronika życia i twórczości Tadeusza-Boya Żeleńskiego, Toruń 2006.

17 W. Łazuga, Ostatni Stańczyk. Michał Bobrzyński - portret konserwatysty, Toruń 2005; W. Wojdyło, Stanisław Grabski (1871-1949). Biografia polityczna, Toruń 2004.

18 Kazimierz Twardowski, Dzienniki, t. 1-2, do druku przygotował wprowadzeniem i przypisami opatrzył R. Jadczak, Warszawa-Toruń 1997.

19 Jerzy Serczyk, Minęło życie, Toruń 1999.

20 Sławomir Kalembka, Urywki wspomnień..., Toruń 2009.

21 B. Szafraniec, Listy Franciszka Bujaka i Ewy Kramszczyk (1902-1909), Toruń 2012.

22 Władysław Maćkowicz, Wspomnienia polskiego nauczyciela Pogranicza 1893-1976, oprac. J. Zdrenka, Toruń 2005.

23 J. Szuścik, Pamiętnik „Życiorys nauczyciela”/ J. Szuścik, wstęp, oprac. i biogram Jana Szuścika oraz indeksy W. Marcoń, Toruń 2011. 
Z kolei, jako przykład wspomnień autora związanego z polityką wymienić można publikację pułkownika Eugeniusza Stefaniaka, który przez 35 lat służył w Ludowym Wojsku Polskim z czego większość w aparacie polityczno-wychowawczym ${ }^{24}$. E. Stefaniak opisuje kulisy wydarzeń z października 1956 i grudnia 1970 r., których był bezpośrednim świadkiem.

Trzecią ważną kategorią prac, jak nazwano w opisie oferty WAM, którą można także określić mianem serii, jest kategoria pt. Księgi Pamiątkowe ${ }^{25}$. Jest to specyficzna forma publikacji, zwłaszcza w przypadku ksiąg jubileuszowych poświęconych polskim uczonym. W publikacjach tych oprócz biografii jubilata znajdujemy wątki autobiograficzne osób mówiących o bohaterze księgi, a zarazem z nim związanych i pozostających w kontaktach naukowych. Niech przykładem w tym zakresie będą księgi poświęcone profesorom historii ${ }^{26}$, politologii ${ }^{27}$, pedagogiki ${ }^{28}$.

Analizując ofertę wydawniczą WAM, warto wyróżnić także czwartą grupę publikacji mówiących o ludziach kultury, nauki, polityki i innych dziedzin życia społecznego. Są to opracowania zbiorowe ${ }^{29}$ i słowniki biograficzne ${ }^{30}$. Stanowią one ważne źródłu do badań naukowych.

Trudno porównywać ofertę WAM (w zakresie biografistyki i literatury pamiętnikarskiej) z innymi wydawnictwami w Polsce, nawet tymi, które są równolatkami toruńskiej oficyny, gdyż każde wydawnictwo ma swój profili ${ }^{31}$. Natomiast zestawienie z wydawnictwami, które mają o wiele dłuższą historię, jak na przykład „Wydawnictwo Literackie" powstałe w 1953 r., pozbawione jest racjonalnego uzasadnienia. Podsumowując uwagi o WAM, należy stwierdzić, że zdobyło ono swoje miejsce i uznanie na rynku wydawniczym w Polsce i nie tylko. A wymienione $w$ tytule tekstu zagadnienie promocji twórców nauki, kultury i polityki prowadzone przez WAM można pojmować $w$ dwoistym znaczeniu. $Z$ jednej strony

${ }^{24}$ E. Stefaniak, Byłem oficerem politycznym LWP, Toruń 2007. Omówienie publikacji w „Nasza Polska", 8 lipca 2008, nr 28.

25 Strona internetowa WAM www.marszałek.com.pl

${ }^{26}$ Homo doctus in se semper divitias habet. Księga Pamiątkowa ofiarowana Profesorowi Januszowi Małtkowi z okazji siedemdziesiątej rocznicy urodzin i pięćdziesiątej rocznicy rozpoczęcia pracy naukowej, red. W. Polak, Toruń 2008.

27 Czesław Mojsiewicz. Mistrz - Wychowawca - Przyjaciel, red. J. Marszałek-Kawa, Toruń 2010.

${ }_{28}$ Poza paradygmaty. Pedagogika międzykulturowa. Księga pamiątkowa dedykowana profesorowi Tadeuszowi Lewowickiemu, red. A. Szczurek-Boruta, E. Ogrodzka-Mazur, t. 1 i 2, Toruń 2012; W kręgu edukacji informatycznej i medialnej. Studia ofiarowane profesorowi Bronisławowi Siemienieckiemu z okazji 60 rocznicy urodzin, 40-lecia pracy naukowej i 20-lecia powstania toruńskiego ośrodka badań nad edukacją informatyczną i medialną, Toruń 2010.

29 Zob.: M. Łysiak, Szkice biograficzne wojennego pokolenia lekarzy toruńskich 1939-1945, Toruń 2001.

30 Zob.: Słownik biograficzny XIX wieku, red. J. Pająk i in., Toruń 2005; Słownik biograficzny polskiej historii wychowania, red. A. Meissner, W. Szulakiewicz, Toruń 2008.

31 Mam na myśli np.: Oficynę Wydawniczą Impuls powstałą w 1990 r. czy Wydawnictwo Semper założone w 1991. 
jest to popularyzacja biografii historycznych, ludzi zasłużonych i niezwykłych oraz ich roli w rozwoju cywilizacji, z drugiej zaś to propagowanie współczesnych nam twórców nauki, kultury i polityki. Wynika to z faktu, jak stwierdził profesor Wojciech Wrzesiński, że „Swoją współpracę Adam Marszałek opierał o współdziałanie nie tylko ze starymi, renomowanymi, doświadczonymi wielkimi uczelniami, które gromadziły duże liczby wytrawnych badaczy wielu dyscyplin, ale nie skąpił pomocy dla powstających młodych środowisk, dopiero walczących o byt na ogólnej mapie polskich środowisk naukowych, także przez lokalne, regionalne, niepaństwowe uczelnie wyższe i to różnego profilu. Adam Marszałek był nie tylko obserwatorem, wyrastania, rozwoju tych środowisk. Często uczestniczył w ich powstawaniu i życiu od pierwszych chwil narodzin, tryumfach, ale i niekiedy porażkach"32.

${ }^{32}$ Dwadzieścia lat minęło... Księga jubileuszowa Wydawnictwa Adam Marszałek, pod red. J. Orzeł, wyd. II poszerzone, Toruń 2010, s. 65-66. 